\title{
Physical and Chemical Properties of Anodised Titanium in Sulphuric Acid for Biomedical Application
}

\author{
Mohamad Ali Selimin ${ }^{1}$, Lee Te Chuan², Maizlinda Izwana Idris ${ }^{3}$, Hasan Zuhudi \\ Abdullah $^{3}$
}

\begin{abstract}
${ }^{1}$ Department of Furniture Design and Manufacturing, Faculty of Technology Management and Business, Universiti Tun Hussein Onn Malaysia, 86400 Batu Pahat, Johor, MALAYSIA.

${ }^{2}$ Department of Production and Operation, Faculty of Technology Management and Business, Universiti Tun Hussein Onn Malaysia, 86400 Batu Pahat, Johor, MALAYSIA.

${ }^{3}$ Department of Materials and Design Engineering, Faculty of Mechanical and Manufacturing Engineering, Universiti Tun Hussein Onn Malaysia, 86400 Batu Pahat, Johor, MALAYSIA.
\end{abstract}

Received 7 January 2018; accepted 23 January 2018, available online 3 July 2018

\begin{abstract}
Fabrication of bioactive titanium (Ti) by using anodic oxidation method for biomedical application as a high-performance material with good biocompatibility properties has been introduced since many years ago. The current study aims to investigate the physical and chemical properties of anodised $\mathrm{Ti}$ oxide layer in sulphuric acid at different applied voltages. High purity Ti films were anodised with varying voltages (50-200 V) in 0.3 M of sulphuric acid at $75 \mathrm{~mA} . \mathrm{cm}^{-2}$ current density for $10 \mathrm{~min}$. Anodised Ti films were characterised for physical properties (colour, porosity, surface morphology, thickness) and chemical property (surface mineralogy). The anodised Ti produced using high voltage $(200 \mathrm{~V})$ appeared to be highly porous and demonstrated high crystallinity of rutile and anatase as well thicker oxide layer. From the results, the correlation between the physical and chemical properties can be used as a prediction of the properties of anodised $\mathrm{Ti}$ in sulphuric acid for a different parameter.
\end{abstract}

Keywords: Anodic oxidation, prediction, biomaterials, titanium thin films, colour

\section{Introduction}

The advanced of medicine and the increase in human life expectancy, there is now a greater need for biomaterials to remedy problems related to the reconstruction of tissues and organs, as well as problems related to injury or diseases attribute to ageing or trauma from accidents [1]. Biomaterials are used for the purpose of biomedical or clinical applications to treat diseases or injuries by replacing or reconstructing broken parts, tissues and organs, or by functioning in close contact with the tissue of live organisms especially humans [2]. Therefore, the development of bone-bonding materials with different mechanical properties is desired.

Titanium (Ti) is biocompatible, lightweight, and corrosion-resistant and has superior mechanical properties. Therefore, they have been widely used in biomedical implants and dental applications. These characteristics make them very suitable elements compared to other biomaterials [3-5]. Ti can be used as a material for an implant after undergoing a surface modification to modify the oxide of the material from bioinert to bioactive. Anodic oxidation is a promising technique that has the ability to enhance the physical and chemical properties of $\mathrm{Ti}$ without changing its microstructure. This method is able to produce anatase and/or rutile phases on the $\mathrm{Ti}$ surface in shorter time, simplest, and cost-efficient compared to other methods such as alkaline treatment, gel oxidation, plasma spraying, and biochemical methods [6-7].

Anodic oxidation is a well-established method to produce different properties of an oxide layer on metals by altering the process parameters such as anode potential, temperature, type of electrolyte, and current [810]. It can be used to increase the thickness of oxide layer by transforming the bioinert $\mathrm{Ti}$ to bioactive $\mathrm{Ti}$ which able to enhance the corrosion resistance properties of the $\mathrm{Ti}$ and decrease the ion release, colouration, and porous (anatase and/or rutile) coatings [6]. Anodic oxidation technique also allows controlling the formation of the oxide layer which is thicker than formed naturally [11]. The properties of the implant surface play a crucial role in facilitating more sites for bone-like apatite nucleation [12]. These properties include porosity, roughness, high crystallinity, and wettability are ideal for enhancing the precipitation process [13].

In this present study, an oxide surface of Ti film was modified by anodic oxidation in sulphuric acid. The applied voltage was varied to investigate the effect of anodic oxidation on $\mathrm{Ti}$ films including the colour of anodic films, surface morphology, surface mineralogy and thickness. The prediction of anodised Ti properties based on the observations during anodic oxidation and its colour will be introduced. 


\section{Materials and Methods}

\subsection{Anodic Oxidation}

High purity Ti films with dimensions $25 \mathrm{~mm} \times 10$ $\mathrm{mm} \times 0.05 \mathrm{~mm}$ were wet hand-polished with 1200 grit silicon carbide $(\mathrm{SiC})$ abrasive paper to remove its naturally formed oxide layer until a shiny metallic surface was obtained [14]. The Ti films were immersed in an ultrasonic bath containing acetone for 3 minutes and rinsed with distilled water prior to being dried with compressed air. Anodic oxidation is carried out in an electrochemical cell containing $0.4 \mathrm{~L}$ solution at $\sim 25^{\circ} \mathrm{C}$. The anode and cathode both are Ti film and the anodising are done with a programmable power supply (Genesys 600-1.3, Densai-Lambda, Japan). Sulphuric acid was used as an electrolyte $(0.3 \mathrm{M})$ at different applied voltages (50$200 \mathrm{~V}$ ) and a current density of $75 \mathrm{~mA} \cdot \mathrm{cm}^{-2}$ for 10 minutes at room temperature. The anodised $\mathrm{Ti}$ films are cleaned by dipping them in $50 \mathrm{~mL}$ of distilled water 3 times, followed by drying them in still air.

\subsection{Characterisation}

The colour of anodic films was recorded using a digital camera (iPhone 5s, Apple) [15]. The mineralogical composition of the anodised films was examined using glancing angle X-ray diffraction, GAXRD (X'Pert ${ }^{3}$ Powder, PANalytical, Netherland) at $40 \mathrm{kV}$ accelerating voltage and $40 \mathrm{~mA}$ of current, angle of incidence of $1^{\circ}$, $0.067^{\circ} / \mathrm{s}$ scanning speed. The surface morphology was determined by using field emission scanning electron microscopy, FESEM (JSM-7600F, Joel Ltd., Japan) at accelerating voltage of $7 \mathrm{kV}$. Meanwhile, the focused ion beam, FIB (Dual beam, Helios NanoLab 650, FEI) was used for cross-sectional imaging (thickness). The pores size was determined by using ImageJ software.

\section{Results and Discussion}

\subsection{Colour of anodic films}

$\mathrm{Ti}$ exhibits various colour because of thin film interference of passive layer. Numerous studies have been done on Ti and its alloys to study the colour of the metals and suggested that the colour of the thin film is strongly dependent on the thickness of the oxide layer and incident angle of light beam [16-17].

Fig. 1 set outs the visual appearance of anodised $\mathrm{Ti}$ prepared using sulphuric acid as a function of applied voltage. According to multi-beam interference theory, the colouring resulted from the interference between the light beams that are reflected from (a) the film surface and (b) the film-substrate interface [18]. The colour of anodic films can be classified into two groups based on the arcing during anodisation and its effects: non-arcing (blueish yellow) and arcing (dark purple and grey).

In this study, the colour variations of anodised $\mathrm{Ti}$ films were influenced by the applied voltage. The films resulted in a greater intensity of arcing in short time at a high current density that leads to micro-arc sparking occurred. This happens due to the higher electrical conductivity of the solution that trigger by higher cell potential (voltage) that raised the temperature on the anode. High temperature can melt the oxide layer that known as localised heating phenomenon. Further anodisation will lead to micro-arc sparking. This phenomenon exists due to the exposure of films substrate to the electrolyte and excessive ions migration from the (rapid electrolyte to exposed Ti Substrate. Meanwhile, the arcing process resulted from the dielectric breakdown reduction in the resistance of an electrical insulator) [19]. Table 1 displays the summary of the colour of anodised Ti films in sulphuric acid.

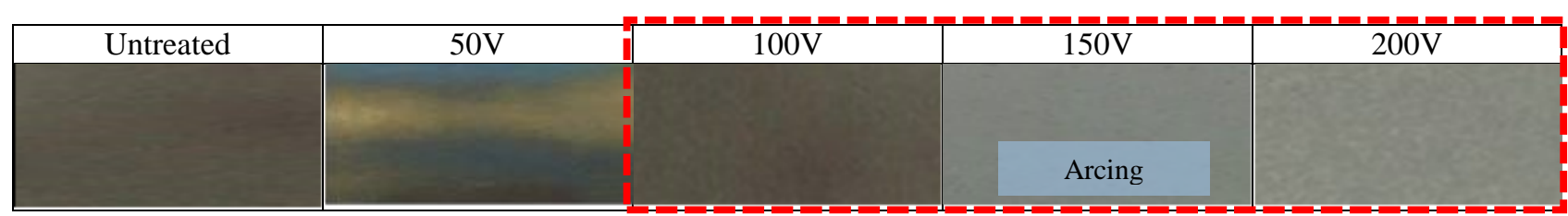

Fig. 1 Colour of anodised Ti films as a function of applied voltages (50-200V).

Table 1 Summary of anodised Ti colour

\begin{tabular}{|c|c|c|c|c|}
\hline & $\begin{array}{l}\text { Voltage } \\
\text { (V) }\end{array}$ & $\begin{array}{l}\text { Arcing } \\
\text { ability }\end{array}$ & Colour & Observation at anode \\
\hline 方: & 50 & Weak & $\begin{array}{l}\text { Blueish } \\
\text { yellow }\end{array}$ & $\begin{array}{l}\text { - Few bubbles were produced and stick on the film } \\
\text { - No white-subsurface due to no arcing occurs }\end{array}$ \\
\hline \multirow{3}{*}{ 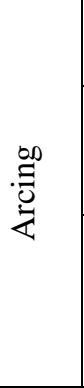 } & 100 & Strong & $\begin{array}{c}\text { Dark } \\
\text { purple }\end{array}$ & $\begin{array}{l}\text { - Numerous bubbles were produced and actively moving to air } \\
\text { - Thin white-subsurface }\end{array}$ \\
\hline & 150 & $\begin{array}{l}\text { Very } \\
\text { strong }\end{array}$ & Grey & $\begin{array}{l}\text { - Numerous and excessive bubbles produced and intensely moving to air } \\
\text { - Thick white-subsurface } \\
\text { - Breakdown voltage observed }\end{array}$ \\
\hline & 200 & $\begin{array}{l}\text { Very } \\
\text { strong }\end{array}$ & $\begin{array}{l}\text { Whitish } \\
\text { grey }\end{array}$ & $\begin{array}{l}\text { - Numerous and excessive bubbles produced and intensely moving to air } \\
\text { - Thick white-subsurface } \\
\text { - Breakdown voltage observed } \\
\text { - Micro-arc sparking occurred }\end{array}$ \\
\hline
\end{tabular}


Table 2 Prediction of anodised Ti properties

\begin{tabular}{|c|c|c|}
\hline Colour & Observations & Possible properties \\
\hline $\begin{array}{l}\text { Blue, yellow, } \\
\text { bright purple, } \\
\text { brown }\end{array}$ & $\begin{array}{l}\sim \text { Onset formation of } \mathrm{O}_{2} \text { bubbles } \\
\sim \text { Bubbles attached on Ti surface } \\
\sim \text { No arcing } \\
\sim \text { Voltage dominant }\end{array}$ & $\begin{array}{l}\sim \text { Smooth and dense morphology } \\
\sim \text { No or low crystallinity of anatase } \\
\sim \text { Thinner oxide } \\
\sim \text { Lowest porosity }\end{array}$ \\
\hline $\begin{array}{l}\text { Bluish purple, } \\
\text { purple }\end{array}$ & $\begin{array}{l}\sim \text { More } \mathrm{O}_{2} \text { bubbles formed } \\
\sim \text { Bubbles are moving upward to the air } \\
\sim \text { Arcing and delectric breakdown occurred } \\
\sim \text { Thin formation of white substance at interface } \\
\quad \text { electrolyte, Ti film and air } \\
\sim \text { Voltage dominant }\end{array}$ & $\begin{array}{l}\sim \text { Uneven morphology } \\
\sim \text { Low anatase and no rutile } \\
\sim \text { Thin oxide } \\
\sim \text { Low porosity }\end{array}$ \\
\hline Grey & $\begin{array}{l}\sim \text { Numerous } \mathrm{O}_{2} \text { evolutions } \\
\sim \text { Bubbles are moving rapid and intense to the air } \\
\sim \text { Arcing and dielectric breakdown occurred } \\
\sim \text { Thick formation of white substance } \\
\sim \text { Current density dominant }\end{array}$ & $\begin{array}{l}\sim \text { Consistent morphology (donut- } \\
\text { shape) and small pores } \\
\text { boundaries } \\
\sim \text { High anatase and/or low rutile } \\
\sim \text { Thick oxide } \\
\sim \text { High porosity }\end{array}$ \\
\hline Whitish grey & $\begin{array}{l}\sim \text { Enormous } \mathrm{O}_{2} \text { evolutions } \\
\sim \text { Bubbles are moving rapid and intense to the air } \\
\sim \text { Arcing and dielectric breakdown occurred } \\
\sim \text { Thicker formation of white substance } \\
\sim \text { Micro-arc sparking observed } \\
\sim \text { Current density dominant }\end{array}$ & $\begin{array}{l}\sim \text { Even morphology (melted donut- } \\
\text { shape) and wider pores } \\
\text { boundaries } \\
\sim \text { High rutile and low anatase } \\
\sim \text { Thicker oxide } \\
\sim \text { Higher porosity }\end{array}$ \\
\hline
\end{tabular}

Based on the results reported in present and previous studies conducted by the author [14-15, 20-21], the prediction of the properties of the anodised $\mathrm{Ti}$ in sulphuric acid such as its morphology and mineralogy can be made based on the anodic oxidation reactions and the colour of the films as shown in Table 2. So far, this prediction is eligible for two types of electrolyte only (sulphuric and acetic acid). Others electrolyte must undergo anodic oxidation to confirm and validate the suitability and reliability of this prediction.

\subsection{Surface morphology (FESEM)}

Fig. 2 shows the surface morphology of anodised $\mathrm{Ti}$ produced at voltages of 50,100, 150, and $200 \mathrm{~V}$. It can be observed that the porosity of the oxide layer increased with applied voltage. Besides that, the number of pores and its size increased with increasing of applied voltage. The formation of pores on Ti surface occurred due to the oxygen gas evaluation, where the oxygen ion transferred into $\mathrm{Ti}$ interface and migration of $\mathrm{Ti}^{4+}$ ion from the $\mathrm{Ti}$ substrate to the film-electrolyte interface at the anode. The effect of applied voltage on the morphology of the films is tabulated in Table 3 and the pore size was calculated by using ImageJ software.

\subsection{Surface mineralogy (GAXRD)}

The mineralogical of anodised $\mathrm{Ti}$ at different voltages of $50-200 \mathrm{~V}$ is illustrated in Fig. 3. The anatase phase (JCPDS No.: 3-7543) revealed in GAXRD results in the early stage of anodisation. Rutile phase (JCPDS No.: 76757) was detected starting at $150 \mathrm{~V}$. As the arcing activity become more intense, the $\mathrm{X}$-ray peaks (major peak) of anatase or rutile gradually increased. At low voltage $(50 \mathrm{~V})$, the low crystallinity of anatase is observed indicates that thin coating of anatase formed on the surface of the film. By increasing the applied voltage to $100 \mathrm{~V}$, the intensity of anatase peaks $\left(25^{\circ} 2 \theta\right.$ is major peak of anatase) increased gradually. Mixtures of anatase and rutile phases were observed at $150 \mathrm{~V}$ to comprise the oxide layer. Further anodisation $(200 \mathrm{~V})$, greater amounts of rutile over anatase were present since the micro-arc sparking occurred during the process. It is well known that the anatase transforms to rutile at a temperature > $600{ }^{\circ} \mathrm{C}[22]$.

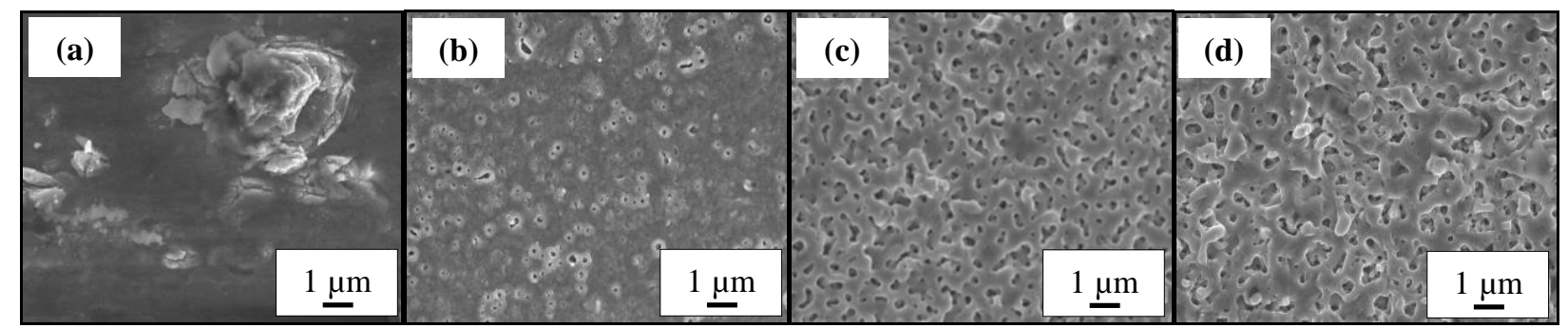

Fig. 2 FESEM micrographs of anodised Ti obtained at different applied voltages: (a) 50V, (b) 100V, (c) 150V, and (d) $200 \mathrm{~V}$. 
International Journal of Integrated Engineering: Special Issue 2018: Seminar on

Postgraduate Study, Vol. 10 No. 3 (2018) p. 48-52

(C) Penerbit UTHM

DOI: https://doi.org/10.30880/ijie.xx.Xx.Xxxx.Xx.Xxxx

Table 3 Summary of surface morphological of anodised Ti at voltages of 50-200V

\begin{tabular}{|c|c|c|c|c|c|c|c|}
\hline \multicolumn{2}{|c|}{ Voltage } & \multirow[t]{2}{*}{ Type of Morphology } & \multirow{2}{*}{$\begin{array}{c}\text { Pore } \\
\text { no. }\end{array}$} & \multirow{2}{*}{$\begin{array}{c}\text { Pore } \\
\text { distribution }\end{array}$} & \multicolumn{3}{|c|}{ Pore size $(\mu \mathrm{m})$} \\
\hline Type & (V) & & & & Mean & Min & Max \\
\hline Low & 50 & Smooth and open cracks & Few & Uneven & \multicolumn{3}{|c|}{ NA } \\
\hline High & 100 & Various porosity & Many & Uneven & 0.170 & 0.078 & 0.404 \\
\hline \multirow{2}{*}{ Very high } & 150 & Consistent porosity & Many & Even & 0.396 & 0.215 & 0.866 \\
\hline & 200 & Consistent porosity & Many & Even & 0.402 & 0.110 & 0.850 \\
\hline
\end{tabular}

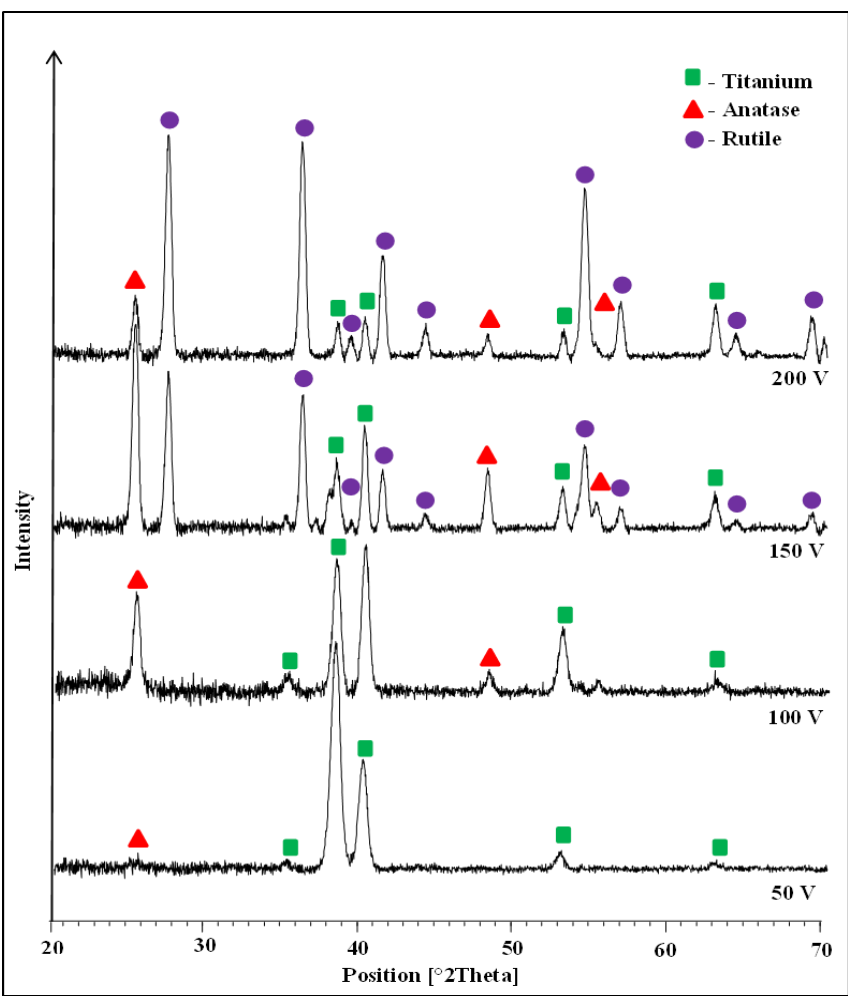

Fig. 3. GAXRD patterns of anodised Ti.

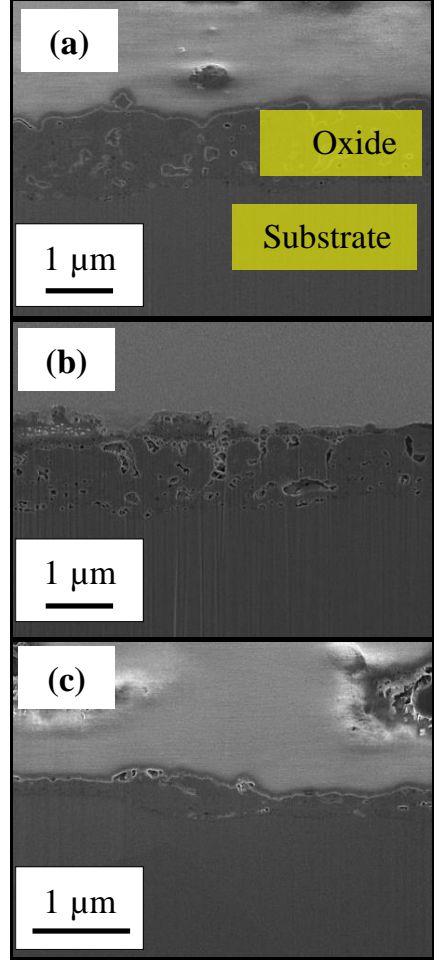

Fig. 4 FIB micrographs of anodised Ti: (a) 100V, (b) $150 \mathrm{~V}$, and (c) $200 \mathrm{~V}$.

Table 4 Summary of GAXRD results and observation on bubbles during anodisation process

\begin{tabular}{|l|l|l|l|l|}
\hline \multicolumn{2}{|c|}{ Voltage } & \multicolumn{2}{c|}{ Type of mineralogy } & \multicolumn{2}{c|}{ Oxygen gas (bubble) at anode } \\
\cline { 5 - 5 } Type & \multicolumn{1}{|c|}{$(\mathrm{V})$} & & Amount & \multicolumn{1}{c|}{ Condition } \\
\hline Low & 50 & Low anatase & Few & Stick on Ti surface \\
\hline High & 100 & High anatase & Many & Some evolve to air (steadily) \\
\hline \multirow{2}{*}{ Very high } & 150 & Very high anatase + high rutile & \multirow{2}{*}{ Enormous } & \multirow{2}{*}{ Continuously evolve to air (rapid) } \\
\cline { 2 - 3 } & 200 & Low anatase + very high rutile & & \\
\hline
\end{tabular}

The summary of GAXRD results and observation on bubbles formed during anodic oxidation process is tabulated in Table 4.

\subsection{Thickness of oxide layer (FIB)}

Fig. 4 shows that FIB images of the cross-section tilted at $54^{\circ}$ of the anodised films. The images consist of two layers (substrate and oxide layer). The images revealed that the thickness of anodised Ti films increased with increasing of applied voltage. At some point (150$200 \mathrm{~V})$, the thickness of the films almost similar even though anodisation reactions not same. The images set out that the thickness of anodised films at $100 \mathrm{~V}, 150 \mathrm{~V}$ and $200 \mathrm{~V}$ are $0.44 \pm 0.20 \mu \mathrm{m}, 1.00 \pm 0.18 \mu \mathrm{m}$, and 1.00 $\pm 0.23 \mu \mathrm{m}$ respectively. The FIB images show that the microstructure (pores or void) of both specimens (150 and $200 \mathrm{~V}$ ) are different despite having similar thickness.

\section{Conclusions}

As for conclusions, the applied voltage has a significant influence on the properties of anodised Ti such as colour, surface morphology, mineralogy, microstructure, and thickness. With the increase in applied voltage, the oxide layer of the film was observed become porous, rougher and thicker. The correlation between the reactions during the anodic oxidation and the 
colour of anodic films can help to predict the surface morphology, surface mineralogy, surface profile, and thickness of its oxide layer. The findings indicate that both the observation and the colour of anodic films are needed to have a better prediction of the properties of the films. Proper parameters combination of anodic oxidation such as applied voltage, current density, type of electrolyte, concentration of electrolyte, treatment duration and much more can influence the intensity of arcing process, which can affect the properties of the films.

\section{Acknowledgements}

The authors gratefully acknowledge the supports of Universiti Tun Hussein Onn Malaysia and Ministry of Higher Education of Malaysia for funding toward this research under Fundamental Research Grant Scheme (FRGS Vot 1212 and Vot 1419). This paper was partly sponsored by Center for Graduate Studies, UTHM.

\section{References}

[1] Zavaglia, C.A.C., and Silva, M.H.P.d. Feature articles: biomaterials reference module in materials science and materials engineering, (2016).

[2] Park, J.B., and Lakes, R.S. Biomaterials: an introduction. Springer of United State, (2007).

[3] Oh, H.J., Lee, J.H., Jeong, Y., Kim, Y.K., and Chi, C.S. Microstructural characterization of biomedical titanium oxide film fabricated by electrochemical method. Surface \& Coatings Technology, Volume 198, (2005), pp. 247-252.

[4] Ma, F., Liu, P., Li, W., Liu, X., Chen, X., He, D., Wang, L., and Geng, F. Effect of applied voltage on the microstructure and bioactivity of MAO film on Ti substrate. Materials Transactions, Volume 54, (2013), pp. 1800-1804.

[5] Rezaei, B. and Mosaddeghi, H. Application of titanium dioxide nanocoating. Nano-technology in environments conference, (2006).

[6] Liu, X., Chu, P.K., and Ding, C. Surface modification of titanium, titanium alloys, and related materials for biomedical application. Materials Science and Engineering R, Volume 47, (2004), pp. 49-121.

[7] Senain, I., Nayan, N., and Saim, H., Structural and electrical properties of $\mathrm{TiO}_{2}$ thin film derived from sol-gel method using titanium (IV) butoxide. International Journal of Integrated Engineering, Volume 2, (2010), pp. 29-35.

[8] Yang, B., Uchida, M., Kim, H.M., Zhang, X., and Kokubo, T. Preparation of bioactive titanium metal via anodic oxidation treatment. Biomaterials, Volume 25, (2004), pp. 1003-1010.

[9] Concha, O., Castaneda, I., Guardian, R., Marban, A., Mayorga, D., Cuentas, K., Uruchurtu, J., Rincon, M., and Menchaca-Campos, C., Formation of porous anodic film on titanium in acid media containing fluoride ions at low over-potentials. International
Journal of Electrochemical Science, Volume 10, (2015), pp. 6175-6186.

[10] Kim, H.M., Kaneko, H., Kawashita, M., Kokubo, T., and Nakamura, T. Mechanism of apatite formation on anodically oxidized titanium metal in simulated body fluid. Key Engineering Materials, Volume 254256, (2004), pp. 741-744.

[11]Sul, Y.T., Johanson, C.B., Yeong, Y., and Albrektsson, T. The electrochemical oxide growth behaviour on titanium in acid and alkaline electrolytes. Medical Engineering Physics, Volume 23, (2001), pp. 329-346.

[12] Campos. D.M., Jr., E.S., Kuromoto, N.K., and Soares, G.A. Preliminary results of osteoblast adhesion on titanium anodic films. Revista Materia, Volume 12, (2007), pp. 150-155.

[13]Lee, T.C., Koshy, P., Abdullah, H.Z., and Idris, M.I. Precipitation of bone-like apatite on anodised titanium in simulated body fluid. Surface \& Coatings Technology, Volume 301, (2015), pp. 20-28.

[14] Selimin, M.A., Idris, M.I., and Abdullah, H.Z. Effect of current density on anodised titanium in sulphuric acid for biomedical application. Materials Science Forum, Volume 840, (2016), pp. 141-145.

[15] Selimin, M.A., Idris, M.I., and Abdullah, H.Z. Characterisation and wettability properties of anodised titanium in sulphuric acid for biomedical application. Materials Science Forum, Volume 840, (2016), pp. 170-174.

[16] Delplancke, J.L., Degrez, M., Fontana, A., and Winand, R. Self-colour anodizing of titanium. Surface Technology, Volume 16, (1982), pp. 153162.

[17] Abdullah, H.Z., Lee, T.C., Idris, M.I., and Sorrell, C.C. Effect of current density on anodised titanium in mixture of $\beta$-glycerophosphate and calcium acetate. Advanced Materials Research, Volume 1087, (2015), pp. 212-217.

[18] Komatsu, I., Aoki, H., Ebisawa, M., Kuroda, A., Kuroda, K., and Maeda, S. Colour change mechanism of biobium oxide thin film with incidental light angle and applied voltage. Thin Solid Films, Volume 603, (2016), pp. 180-186.

[19] Tengvall, P., Elwing, H., Sjoqvist, L., Lundstrom, I., and Bjursten, L.M. Interaction between hydrogen peroxide and titanium: a possible role in the biocompatibility of titanium. Biomaterials, Volume 10, (1989), pp. 118-120.

[20] Selimin, M.A., Malik, Z., Anjang, N., Idris, M.I., and Abdullah, H.Z. Surface characterisation of bioactive titanium formed via anodic oxidation. Seek Digital Library, (2015), pp. 27-31.

[21] Selimin, M.A., Malik, Z., Anjang, N., Idris, M.I., and Abdullah, H.Z. Effect of sulphuric acid concentration on anodised titanium for biomedical application. Seek Digital Library, (2015), pp. 46-50.

[22] Hanaor, D.A., and Sorrell, C.C. Review of the anatase to rutile phase transformation. Journal of Material Science, Volume 46, (2011), pp. 855-874. 